\title{
Sociological aspects of alcoholism as a social deviation in Bosnia and Herzegovina*
}

\author{
B.Č. Milošević Šššo \\ University of East Sarajevo \\ Alekse Šantića St., 1, 71000, Republic of Srpska, Bosnia and Herzegovina
}

(e-mail: milosevic_biljana@yahoo.com)

\begin{abstract}
There has always been an interest in social-pathological problems in the society. Documents confirming our wish to find out the causes of 'other' types of behavior as opposed to the 'usual'/accepted types date back to the Ancient and Middle Ages. The social significance of the study of social-pathological phenomena is evident for they allow to reveal dysfunctionalities in certain structural elements or failed socialization, which are most probably determined by destabilization of the social system and value priorities. Alcoholism as a form of deviant behavior is usually considered the most common and influential factor of destroying the physical and psychological health and of negative changes in human behavior. The article describes the level of alcoholism and the ways of perceiving it in Bosnia and Herzegovina based on the empirical data collected within the broader scientific study of the social changes in one part of Bosnia and Herzegovina - Republic of Srpska. The survey was conducted on the representative sample of 220 respondents (reflecting the social-demographic and social-economic characteristics of the general population) in 7 municipalities of the Republic of Srpska. The questionnaire consisted of both closed and partly open questions to reveal the opinions of the respondents on specific deviant forms of behavior and to find out whether the respondents are engaged in some of these deviant forms depending on their attitudes and knowledge about them.
\end{abstract}

Key words: alcoholism; deviation; deviant forms of behavior; Republic of Srpska in Bosnia and Herzegovina; sociological survey; empirical indicators

Society is not an imaginary notion; therefore, many forms of deviant behavior are caused or made possible by social environment. Both normal and pathological behavior, like any other dichotomy of human existence, demands an understanding of the social situation [11]. The need to study the social-pathological behavior on the basis of the scientific principles (objectivity, reliability and especially universality) is evident, but we can choose the focus, for instance, mechanisms for removing or mitigating negative deviations. One of the most widespread social-pathological forms of behavior is alcoholism, mainly due to its ritual nature: almost every event of any significance in our lives needs some sort of ceremony or celebration, which in most cultures involve alcohol. Despite the widely accepted opinion that alcoholism should be considered a medical problem, it is clear that alcoholism is a complex social problem, the most common and most influential factor of human behavior disorders, and an addictive disease together with cardiovascular and cancer diseases prevailing in mortality causes [3. P. 21]. Alcohol has been a pleasure and a problem to mankind since the ancient civilization for drinking

* C B.Č. Milošević Šošo, 2020.

The article was submitted on 15.07.2019. The article was accepted on 03.09.2019. 
is essentially a social act determined by a variety of rules and norms on who can drink what, when, where, with whom and so on. Therefore, an alcoholic is a person who, "due to the overuse and long consumption of alcohol, became addictive to it (psychologically, physically or in both ways) and due to this addiction suffers both health problems (psychological or/and physical) and social difficulties, which can be identified through traditional medical and social diagnostic procedures" [5].

Alcohol consumption and alcohol related problems vary, but their burden is significant in most of the countries. According to World Health Organization (WHO), alcohol consumption is the third global risk factor for over 60 diseases and disabilities in the middle-income countries [15]. Almost 4\% of all deaths around the world are attributed to alcohol, which is more than caused by the HIV/AIDS, violence or tuberculosis. Alcohol is also a factor of many serious social problems including violence, neglect and child abuse, unemployment. About 23 million Europeans are dependent on alcohol annually: $5 \%$ of drinking men and $2 \%$ of drinking women report its negative impact on their work, studies and family relations. Almost half of the global male population and two thirds of the global female population did not consume any alcohol last year, and the abstinence rates are lower in the high-income and high-consumption countries and higher in Northern Africa and Southern Asia with predominantly Muslim population. Societies in which alcohol is traditionally an accepted and morally neutral element of everyday life (like Italy, Spain, France and Greece) tend to favor visible drinkingplaces with large windows and open spaces, so that the drinking-places extend physically into the environment, merge with the everyday world, and "the consumption of alcohol is integrated into common behaviors as sleeping or eating" [10].

In the late $19^{\text {th }}$ - early $20^{\text {th }}$ century, alcohol addicts were often considered as morally wrong, bad people or sinners. This type of thinking made many physicians fight to change such common perceptions in order to help the addicts instead of punishing them. The formation of 'AA' (Alcoholics Anonymous) in the 1930s and publication of the book by E.M. Jellinek [7], the famous psychiatrist and head of the Center of Alcohol Studies at the Yale Medical School, defined alcoholism as a disease instead of a deviant behavior, which made its medical treatment more accessible. Many medical and insurance organizations recognize addiction as a physical malady that needs to be treated. Moreover, the term 'disease' implies a chronic illness and a hope for treatment.

Opinion polls on alcohol reflect public concerns about alcohol related harm and reveal drinking patterns and problems in general, they were first conducted in the Nordic countries about 70 years ago. The countries of Central Europe started their alcohol surveys in the 1960s and 1970s, when it became clear that alcoholism would not disappear in the new socialist societies and that a comprehensive policy is needed to address alcohol related problems. In the last decades of the $20^{\text {th }}$ century, surveys on alcohol were conducted in the remaining European countries including wine-producing areas in Southern Europe and the Eastern-European countries that reemerged after the fall of the socialist regime. Although the WHO had already put alcohol on its public health agenda in the 1980s, the first EU alcohol strategy was developed only in 2006: it had an important symbolic meaning but did not promote evidence-based policies. Nevertheless, the European Commission allocated significant resources on alcohol research including the standardized comparative surveys on alcoholism 
in 10 EU countries representing different drinking cultures and traditions: the Czech Republic, Estonia, Finland, Germany, Hungary, Italy, Ireland, Poland, Spain and the United Kingdom. The project aimed at developing a standardized comparative survey methodology on alcohol consumption, drinking, drunkenness, context of drinking, alcohol dependence, unrecorded alcoholism and public support for alcohol policy. Thus, the Northern-European males reported lower drinking compared to males in other regions, whereas females reported rather higher drinking; moreover, the frequency of episodic heavy drinking was high. The results of the studies showed that for the Central-European countries a rather problematic drinking behaviour was typical - with moderate abstention rates but the highest frequency of drinking, high drinking quantities and a high frequency of episodic heavy drinking. In the two Eastern-European countries respondents showed comparably high rates of abstention in the European context and rather low drinking frequencies; average drinking quantities were high among males but low among females; episodic heavy drinking was less frequent compared to other regions.

Unfortunately, no such studies were conducted in Bosnia and Herzegovina, that is why we conducted a small research on alcohol within a broader scientific study of social changes in one part of Bosnia and Herzegovina - 7 municipalities of the Republic of Srpska (East Sarajevo, Banjaluka, Trebinje, Pale, Šekovići, Rogatica and Doboj). The first part of the questionnaire included questions on the social-demographic characteristics of respondents. The second part of the survey included questions about their opinions on different deviations, whether they were participants or actors in some forms of deviant behavior, and about their knowledge and attitudes to such forms.

According to the survey results, among the mentioned deviations (violence, criminality, alcoholism, gambling, drug addiction, suicide attempts) alcoholism is present in $10,5 \%$ of cases and followed by violence $(9,1 \%)$ and gambling $(7,7 \%)$. An alcoholic would be a person drinking more than he/she can take even after realizing the harmful consequences of one's alcohol consumption [13]. Figures 1 and 2 present the data on the relationship between gender and alcohol consumption: males are more prone to alcoholism $(6,7 \%$ consume alcohol on regular basis vs $1,8 \%$ of female respondents, $37,1 \%$ - occasionally vs $12,4 \%$ ), although $56,2 \%$ (vs $85,8 \%$ ) claim that regular alcohol consumption is not their habit.

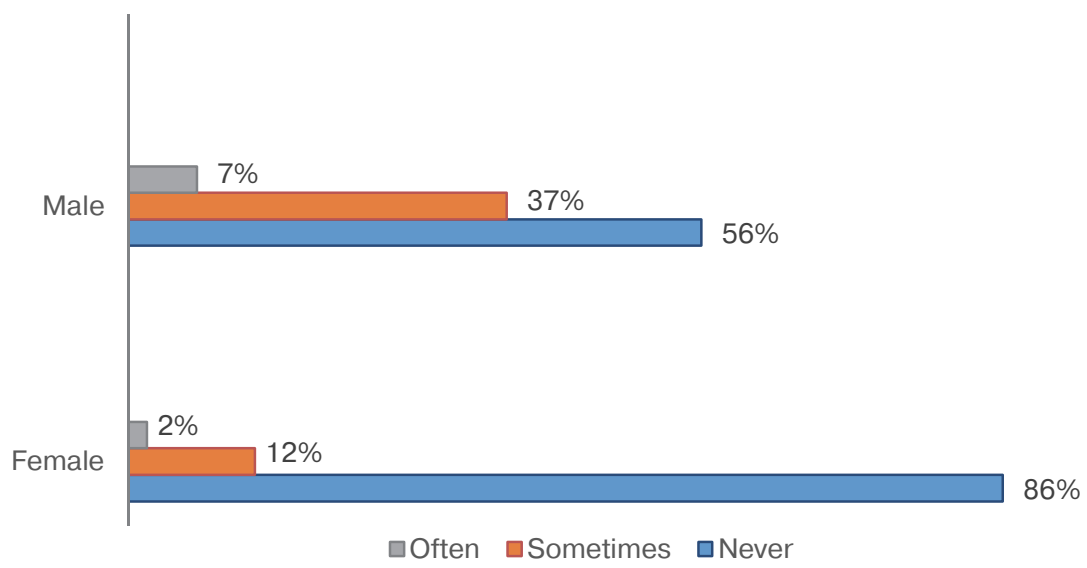

Figure 1. Regular alcohol consumption by gender 


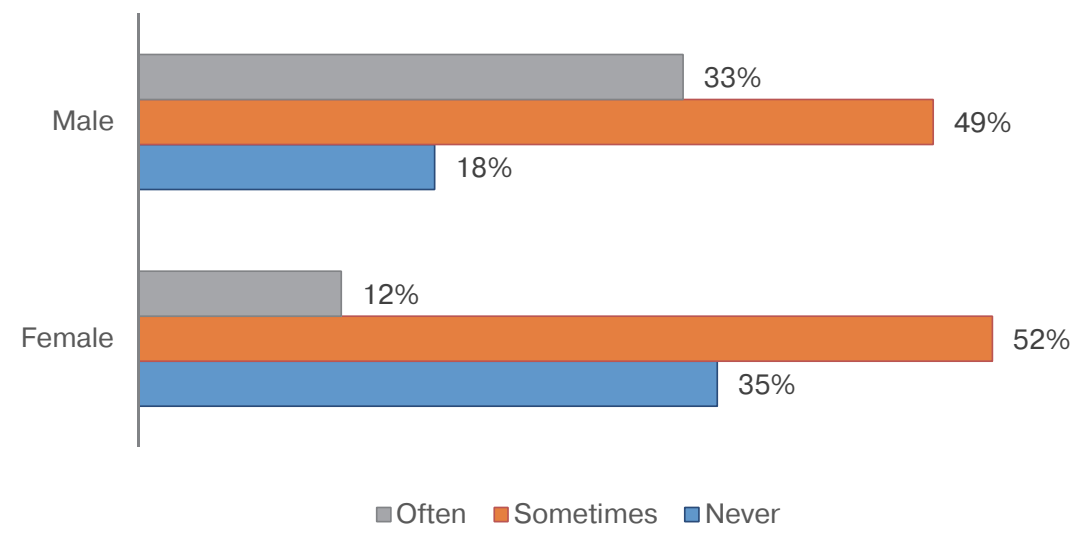

Figure 2. Consumption of alcohol on special occasions by gender

These results prove the social-cultural factors of alcoholism [12]: traditions, perception of alcohol as a sign of masculinity, etc. This is also confirmed by the average number of drinking days in the last 12 months by gender: "Among males, the highest frequency was found in Hungary (50,6 days), the lowest in Slovenia (8,5 days). Among females, Scotland showed the highest level (22,6 days), and Portugal the lowest (3,2 days)" [13. P. 707]. Heavy episodic drinking with meal prevails in Bulgaria (83\% of risky single occasion drinkers drunk $40 / 60$ grams of $100 \%$ alcohol on one occasion with meal in the last 12 months) and Poland (70\%), then come Spain-Catalonia (51\%), Croatia (46\%), Finland (44\%) and Spain (42\%). In the social-cultural perspective, occasional alcohol consumption (on special occasions) should be considered as a way of strengthening social cohesion and not as an excuse for frequent alcohol consumption (on everyday basis). The studies show that gender ratios exceeding 1 implied higher drinking frequencies among males as compared to females [3; 4]: the greatest gender differences were found in Portugal (gender ratio $=6,7$ ), the smallest - in England (1.2); without exception males had an increased rate of drinking more frequently. According to Figure 2, occasional alcohol consumption is still more typical for the male population.

The WHO identified four social-cultural reasons that determine differences in male and female patterns of alcohol consumption: power, sexual behavior, risk, and responsibility. Throughout history, in different cultures alcohol consumption was allowed exclusively for men as a superior and more privileged gender. Alcohol reduces social constrains and influences the part of the brain responsible for the self-control, so both sexes enter sexual relations more easily under the alcohol overuse. Society still tends to condemn more strictly the promiscuity of women, that is why they are more pressured to refuse alcohol. When responsibility is concerned, universal differences in alcohol consumption among men and women prove that society imposes more responsibility on women (family duties), which is also the reason why women are more 'monitored' by a society or community so that deviant behavior would not distract them from the prescribed roles. However, there are reasons why the gap between men and women in relation to alcohol is narrowing: today women are less concerned about the stigma associated with heavy alcohol consumption; the increase in home delivery of alcohol contributes to the ability of women to avoid the stigma and drink more than at a bar or when buying alcohol in person; mental health disorders like depression, anxiety and 
others are linked to an increased rate of alcoholism, and women are more likely to be diagnosed with these disorders than men. Nevertheless, alcohol consumption is still considered a type of risk, it is assumed that men are generally more prone to risky behavior and perceive risk as more appealing and as an expression of masculinity, which make men drink more than women. Some believe that, regardless of gender, anxiety makes us turn to alcohol to relieve our stress, that to interact with others we drink to relax and often drink too much or too frequently. Thus, there are "abstaining cultures, ambivalent cultures, allowing cultures and too indulgent cultures" [13. P. 706].

Social-cultural aspects of alcoholism were examined by Edwin Lemert in his theory of primary and secondary deviations [8]. He believes that attitudes to alcohol are always contradictory, because on some occasions alcohol beverages are an inevitable and desirable 'companion', while in other cases they are considered the main source of personal and social destruction [8. P. 46). If a person's behavior breaks certain rules of the community, it is a primary, symptomatic or situational deviation as long as it remains within the acceptable social role. If deviant acts repeat in the environment that strongly condemns them, and this condemnation becomes a part of personal identity accepted by the individual, then there is a great probability that existing social roles/expectations will be disrupted [6. P. 336]. By accepting a deviant alternative, an individual enters the second deviation.

The attitudes to alcohol consumption are determined not only by social-cultural but also by social-economic factors (like unemployment). According to Figure 3, the data of our survey show that $36,7 \%$ of the unemployed often consume alcohol on special occasions that are often 'invented occasions' - an excuse for drinking [see also: 4. P. 50]. In the study conducted in the EU, the results show that, with the exception of Latvia, people of the low socio-economic status are more prone to alcoholism.

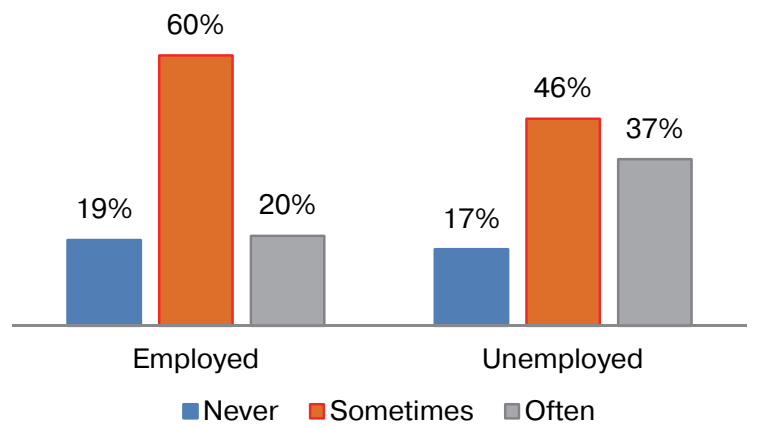

Figure 3. Consumption of alcohol on special occasions by working status

There are many studies of the connection between alcohol addiction and marital status, which show that the marital status can influence this addiction: couples drink less than singles; a person that used to have an alcohol addiction before marriage later consume less alcohol. Many factors explain this phenomenon (less free time, feeling of responsibility, one's identification as a more mature person), and the same applies to the explanation of divorce as a factor of alcohol overuse. For divorced, separated or widowed, alcohol can be a way to relieve stress and face one's losses. Our survey data 
(Table 1) show that singles are more prone to the frequent regular consumption of alcohol (3\%) together with divorced (10\%) and widowed (20\%). The relationship between marital status and alcohol consumption is even more evident if we consider alcohol consumption on special occasions (Table 2): single respondents often consume alcohol on special occasions (29\%), the same applies to the divorced and widowed $(20 \%)$.

Table 1

\section{Regular alcohol consumption by marital status}

\begin{tabular}{|l|c|c|c|}
\hline \multirow{2}{*}{ Marital status } & \multicolumn{3}{|c|}{ Alcohol consumed every day } \\
\cline { 2 - 4 } & Never & Sometimes & Often \\
\hline Married & $73,4 \%$ & $26,6 \%$ & 0 \\
\hline Single & $69 \%$ & $28 \%$ & $3 \%$ \\
\hline Divorced & $60 \%$ & $30 \%$ & $10 \%$ \\
\hline Widowed & $70 \%$ & $10 \%$ & $20 \%$ \\
\hline Non-marital partnership & $80 \%$ & $20 \%$ & 0 \\
\hline
\end{tabular}

Table 2

Consumption of alcohol on special occasions by marital status

\begin{tabular}{|l|c|c|c|}
\hline \multirow{2}{*}{ Marital status } & \multicolumn{3}{|c|}{ Alcohol consumed on special occasions } \\
\cline { 2 - 4 } & Never & Sometimes & Often \\
\hline Married & $25,5 \%$ & $57,4 \%$ & $17 \%$ \\
\hline Single & $22 \%$ & $49 \%$ & $29 \%$ \\
\hline Divorced & $40 \%$ & $40 \%$ & $20 \%$ \\
\hline Widowed & $40 \%$ & $40 \%$ & $20 \%$ \\
\hline Non-marital partnership & $80 \%$ & $10 \%$ & $10 \%$ \\
\hline
\end{tabular}

Perhaps, alcohol is considered as a way to escape the everyday routine and obligations since the society of Bosnia and Herzegovina belongs to the 'allowing cultures', i.e. alcohol consumption here is allowed as 'normal' but that there is a negative reaction to the drunkenness. Most alcoholics in the region are of the middle age (probably, it is due to the fact that alcoholism is a chronic disease), and about $15 \%$ of the population have some alcohol issues including the younger generation. According to the data from the Anonymous Alcoholics in Banjaluka, their youngest member was 33 years old. Table 3 shows that the group of 18-24-year-olds frequently consume alcohol on special occasions $(31,7 \%)$, the same applies to the group of $25-31$-year-olds $(27,8 \%)$. Dragišić Labaš believes that "the greatest rates of alcohol addiction are among the population between 18-24-year-olds, and one in five here is diagnosed as an alcoholic" [4. P. 41]. She found out that over time alcohol and drugs become linked to anger and aggression for their ability to alter neurotransmitter levels allows them to change the mood and affect personal characteristics and propensity for violence [2;16]. However, the social context of drinking is no less important for the alcohol related aggression, and Table 4 presents some potential factors of violence against women: problems with alcohol and drug addiction together with gambling are considered by the respondents as the most influential factors of violence against women. Thus, $84,5 \%$ of respondents believe that alcohol addiction of partners is a potential factor of violence against women, $85,9 \%$ name drug addiction, $75 \%$ - gambling. 


\begin{tabular}{|c|c|c|c|}
\hline \multirow{2}{*}{ Alcohol consumption on special occasions by age } \\
\hline \multirow{2}{*}{ Age } & \multicolumn{2}{|c|}{ Alcohol consumed on special occasions } \\
\cline { 2 - 4 } & Never & Sometimes & Often \\
\hline $18-24$ & $17,5 \%$ & $50,8 \%$ & $31,7 \%$ \\
\hline $25-31$ & $11,1 \%$ & $61,1 \%$ & $27,8 \%$ \\
\hline $32-38$ & $41,5 \%$ & $41,5 \%$ & $17 \%$ \\
\hline $39-45$ & $20,8 \%$ & $54,2 \%$ & $25 \%$ \\
\hline $46-52$ & $30,8 \%$ & $57,7 \%$ & $11,5 \%$ \\
\hline $53-59$ & $33,3 \%$ & $60 \%$ & $6,7 \%$ \\
\hline $60-66$ & $50 \%$ & $50 \%$ & 0 \\
\hline older than 66 & $63,6 \%$ & $18,2 \%$ & $18,2 \%$ \\
\hline
\end{tabular}

Table 4

Potential factors of violence against women (\%)

\begin{tabular}{|l|c|c|c|}
\hline \multicolumn{1}{|c|}{ Potential factors } & Yes & No & No reply \\
\hline Household size & 19,1 & 71,7 & 8.2 \\
\hline Economic status of woman & 47,7 & 45,5 & 6,8 \\
\hline Material deprivation & 51,4 & 16,4 & 7,3 \\
\hline Common disagreements & 53,2 & 16,4 & 5 \\
\hline Low level of education & 53,6 & 40 & 6,4 \\
\hline Patriarchal type of family & 53,2 & 39,1 & 7,7 \\
\hline Previous marriage experience & 39,1 & 54,5 & 6,4 \\
\hline Infidelity & 80,5 & 15 & 4,5 \\
\hline Alcohol addiction & $\mathbf{8 4 , 5}$ & 11,8 & 3,6 \\
\hline Drug addiction & $\mathbf{8 5 , 9}$ & 10,9 & 3,2 \\
\hline Gambling addiction & $\mathbf{7 5}$ & 19,1 & 5,9 \\
\hline Participation in the 1990s wars & 47,3 & 45 & 7,7 \\
\hline Problems with children behavior & 36,4 & 56,8 & 6,8 \\
\hline Women with disabilities & 20,5 & 71,8 & 7,7 \\
\hline Sick women & 20,5 & 71,8 & 7,7 \\
\hline Division of house chores & 18,2 & 74,1 & 7,7 \\
\hline
\end{tabular}

The problem of alcoholism is a social-pathological one, that is why it should be treated as a family one rather than an individual one [1. P. 96]. In the above-mentioned European study, alcohol was proved to increase the number of problematic forms of behavior: the share of people who were involved in a physical fight over alcohol in the last 12 months was the highest in Latvia (8,5\%) and Finland $(4,4 \%)$ and the lowest in Portugal $(0,2 \%)$ and Slovenia $(0,4 \%)$; the 12-month alcohol-related injuries ranged from $0,7 \%$ in Slovenia to $8,9 \%$ in Iceland; the highest share of people with a blackout after drinking was found in Denmark (23,8\%), the lowest in Portugal $(4,1 \%)$; the share of people who experienced physically dangerous situations due to alcohol was the highest in Germany (5,3\%) and the lowest in Sweden (0,6\%); feelings of guilt after drinking are rare for Portugal (2,9\%) and typical for Iceland (29,9\%).

In our survey, we considered the problem of domestic violence determined by the alcohol consumption because families of alcoholics face many problems that "change the quality of communication and emotional relations and affect the psychological health of children and other members of the family" [3. P. 80]. The basic characteristics of alcoholics' families are dysfunctional relationships that lead to their social isolation, lack of social contacts within the family, aggressiveness and family structure disorder [1. P. 96]. 
The problem of alcoholism in Bosnia and Herzegovina became especially acute after the end of the last war, and its causes are mainly social-cultural. Our study confirmed that alcoholism is recognized by the population as one of the most common deviant forms of behavior and is present in every tenth family with men being more inclined to alcoholism than women. However, the level of alcoholism among women grows, which turns it into a long-term problem in the society of Bosnia and Herzegovina, because it represents an 'allowing culture' in which alcohol consumption is allowed and only drunkenness is perceived very negatively. Another important factor affecting the level of alcoholism is social-economic: unemployment is an especially risky life condition for it leads to poverty and social isolation, and the unemployed drink more alcohol and more often by 'inventing' special occasions and excuses for it. Many researchers, on the contrary, emphasize the connection between alcohol addiction and marital status saying that marital status can influence addiction to alcohol: married couples drink less alcohol and have longer breaks between drinkings. There are also age differences in alcohol addiction though they are changing: every tenth representative of the younger generation drinks frequently, but the greatest number of alcoholics is still middle-aged. Moreover, despite all mentioned differences, alcoholism is always a potential risk factor of violence for families of alcoholics have dysfunctional relationships and are often isolated from the community. Sociological surveys can provide necessary information so that the society would be aware of all aspects and risks of alcoholism and take necessary measures against it, primarily the preventive ones.

\section{References}

[1] Bošković M. Social Pathology. Novi Sad; 2007 (In Serbian).

[2] Cherpitel C.J. Alcohol and violence-related injuries in the emergency room. Recent Developments in Alcoholism. 1997; 13.

[3] Dragišić Labaš S. Alcoholism in the Family and Families in Alcoholism. Beograd; 2012 (In Serbian).

[4] Dragišić Labaš S. The alcohol use among adolescents and young adults. Sociološki Pregled. 2012; 49 (1) (In Serbian).

[5] Hudolin V. Alcoholism - a Lifestyle of Alcoholics. Zagreb; 1997 (In Croatian).

[6] Ignjatović Dj. Theory of Criminology. Beograd; 1997 (In Serbian).

[7] Jellinek E.M. Disease Concept of Alcoholism. College and University Press; 1960.

[8] Lemert E.M. Devianza, problemi sociali e forme di controllo. Milano; 1981.

[9] Mavero-Milanesi A. Prevenzione dell'alcolismo II pensiero scientifico. Rim; 1987.

[10] Martinez R.N., Martin L. Patrones de consumo de alcohol en la comunidad de Madrid. Comunidad y Drogas. 1987; 5-6.

[11] Opalić P. Psychiatric Sociology. Beograd; 2008 (In Serbian).

[12] Pittman D.J. Alcoholism. New York; 1967.

[13] Štifanić M. Alcoholism and social sciences. Društvena Istraživanja. Zagreb; 1995 (In Croatian).

[14] Vaillant G. The Natural History of Alcoholism Revised. Massachusetts; 1995.

[15] WHO: Alcohol, gender and drinking problems. http://www.who.int/substance_abuse/ publications/alcohol_gender_drinking_problem.

[16] Zhang L., Wieczorek W., Welte J. The nexus between alcohol and violent crime. Alcoholism: Clinical and Experimental Research. 1997; 21. 


\title{
Социологические аспекты алкоголизма как социальной девиации в Боснии и Герцеговине*
}

\author{
Б.Ч. Милошевич Шошо \\ Университет Восточного Сараево \\ Ул. Алексе Шантича, 1, 71000, Республика Сербская, \\ Босния и Гериеговина \\ (e-mail:milosevic_biljana@yahoo.com)
}

\begin{abstract}
На протяжении всей своей истории общество неизменно проявляло интерес к разного рода социально-патологическим состояниям. Источники подтверждают наше извечное желание обнаружить причины «иных» типов поведения, противопоставленных «обычным»/социально приемлемым, начиная с древнейших времен и эпохи средневековья. Социальное значение исследований социально-патологических феноменов очевидно: полученные данные позволяют обнаружить дисфункциональные проявления в структурных элементах социальной жизни или провалы социализации, которые, вероятнее всего, обусловлены дестабилизационными тенденциями в социальной системе или в ее мировоззренческих доминантах. Алкоголизм как особая форма девиантного поведения обычно считается одним из самых распространенных и влиятельных негативных факторов, разрушающих физическое и психологическое здоровье человека и пагубно сказывающихся на индивидуальном и групповом поведении. В статье представлены показатели, характеризующие уровень алкоголизма и особенности его восприятия на основе эмпирических данных, которые были получены в рамках тематически более широкого научного исследования в одной части Боснии и Герцеговины - Республике Сербской. Опрос был проведен на репрезентативной выборке в 220 респондентов (отражающей социально-демографические и социально-экономические характеристики генеральной совокупности) в семи муниципалитетах Республики Сербской. Анкета состояла из закрытых и полузакрытых вопросов, призванных выявить отношение респондентов к особым формам девиантного поведения и определить, задействованы ли респонденты в таковых, с учетом их отношения и знаний о соответствующих формах девиаций.
\end{abstract}

Ключевые слова: алкоголизм; девиация; девиантные формы поведения; Республика Сербская в Боснии и Герцеговине; социологическое исследование; эмпирические индикаторы

* ( С Милошевич Шошо Б.Ч., 2020.

Статья поступила 15.07.2019 г. Статья принята к публикации 03.09.2019 2. 